\title{
Viability of Human Adenovirus from Hospital Fomites
}

\author{
Ana Carolina Ganime, ${ }^{1 *}$ Filipe A. Carvalho-Costa, ${ }^{1}$ Marisa Santos, ${ }^{2}$ Rubens Costa Filho, ${ }^{3}$ \\ José Paulo G. Leite, ${ }^{1}$ and Marize P. Miagostovich ${ }^{1}$ \\ ${ }^{1}$ Laboratory of Comparative and Environmental Virology, Oswaldo Cruz Institute, Oswaldo Cruz Foundation, \\ Rio de Janeiro, Brazil \\ ${ }^{2}$ National Institute of Cardiology, Rio de Janeiro, Brazil \\ ${ }^{3}$ Pró-Cardíaco Hospital, Rio de Janeiro, Brazil
}

The monitoring of environmental microbial contamination in healthcare facilities may be a valuable tool to determine pathogens transmission in those settings; however, such procedure is limited to bacterial indicators. Viruses are found commonly in those environments and are rarely used for these procedures. The aim of this study was to assess distribution and viability of a human DNA virus on fomites in an Adult Intensive Care Unit of a private hospital in Rio de Janeiro, Brazil. Human adenoviruses (HAdV) were investigated in 141 fomites by scraping the surface area and screening by quantitative PCR (qPCR) using TaqMan ${ }^{\circledR}$ System (Carlsbad, CA). Ten positive samples were selected for virus isolation in A549 and/or HEp2c cell lines. A total of 63 samples $(44.7 \%)$ were positive and presented viral load ranging from $2.48 \times 10^{1}$ to $2.1 \times 10^{3}$ genomic copies per millilitre $(\mathrm{gc} / \mathrm{ml})$. The viability was demonstrated by integrated cell culture/nested-PCR in 5 out of 10 samples. Nucleotide sequencing confirmed all samples as HAdV and characterized one of them as specie $B$, serotype 3 (HAdV-3). The results indicate the risk of nosocomial transmission via contaminated fomites and point out the use of HAdV as biomarkers of environmental contamination. J. Med. Virol. 86:20652069, 2014. (c) 2014 Wiley Periodicals, Inc.

KEY WORDS: adenovirus; viability; fomites; hospital; biomarker

\section{INTRODUCTION}

Studies performed in hospitals have described the transmission of pathogens through contact with contaminated fomites in these environments [Gallimore et al., 2004, 2005, 2006, 2008; Goodman et al., 2008;
Carducci et al., 2011; Ganime et al., 2012]. Particularly, in the case of viruses, experimental, and epidemiological studies indicate that hospital surfaces could play an important role in the spreading of human adenoviruses (HAdV), group A rotaviruses (RVA), and noroviruses (NoV) suggesting that they might be responsible for $15-30 \%$ of nosocomial infections [Soule et al., 1999; Gallimore et al., 2004, 2005, 2006, 2008; Lopman et al., 2004; Rzezutka and Cook, 2004; Sattar, 2004; Goodman et al., 2008; Carducci et al., 2011; Ganime et al., 2012].

Procedures carried out in healthcare facilities could be one of the main sources of viral dissemination, causing considered impact on human health [Tuladar et al., 2012]. In those settings, blood-borne, air borne and viruses transmitted via the fecal-oral route could be easily transmitted by accidents with infected needles or sharp objects or spread by contamination of air, hands, and fomites [Aitken and Jeffries, 2001; Lopman et al., 2004; Davanzo et al., 2008].

Grant sponsor: Brazilian National Council for Scientific and Technological Development (CNPq); Grant sponsor: Oswaldo Cruz Institute (IOC-Fiocruz); Grant sponsor: Program of Research Excellence (PROEP); Grant sponsor: Carlos Chagas Filho Foundation for Research Support of the state of Rio de Janeiro (FAPERJ); Grant sponsor: Instituto Oswaldo Cruz-IOC, Cellular and Molecular Biology Program

This research study is under the scope of the activities of Fiocruz as a collaborating centre of PAHO/WHO of Public and Environmental Health.

Conflicts of Interest: The authors inform that they do not have any conflict of interest.

Ethical Approval: This project was approved by the Hospital's Ethics Committee under number 275/2008.

${ }^{*}$ Correspondence to: Ana Carolina Ganime, Avenida Brasil, 4365, Pav. Hélio \& Peggy Pereira, Manguinhos, Rio de Janeiro 21040-360, Brazil. E-mail: acganime@ioc.fiocruz.br

Accepted 27 January 2014

DOI 10.1002/jmv.23907

Published online 11 July 2014 in Wiley Online Library

(wileyonlinelibrary.com). 
The monitoring of environmental microbial contamination in healthcare services could be a valuable tool to determine the means of transmission. However, this monitoring is usually limited to bacterial indicators and viruses are rarely used, even being common pathogens in hospitals and healthcare settings [Sattar, 2004; Creamer and Humphreys, 2008; Carducci et al., 2011; Ganime et al., 2012].

When compared with RNA viruses, DNA viruses are known to be more stable as they are considered good indicators of viral contamination in environmental samples [Puig et al., 1994; Horwitz, 1996; Pina et al., 1998; Bofill-Mas et al., 2000; Thurston-Enriquez et al., 2003; Carducci et al., 2011]. Particularly, human adenoviruses (HAdV) present several characteristics that qualify them as good viral indicators considering their resistance to environmental stressors, transmission by different routes, and also for not exhibiting seasonality [Myrmel et al., 2006; Haramoto et al., 2007a,b; Katayama et al., 2008]. Additionally, they could be replicated in several cell lines such as A549, HeLa, HEK 293, and HEp-2, among others enabling studies of infectivity and risk assessment [Leite et al., 1985; Rigotto et al., 2005; Filho et al., 2007; Cromeans et al., 2008]. Therefore, the aim of the present report was to investigate HAdV dissemination and viability in fomites obtained in a private hospital in Rio de Janeiro, Brazil. Results of previous investigations on rotavirus A (RVA) using the same samples were published elsewhere and were used to design this study [Ganime et al., 2012].

\section{METHODS}

\section{Sampling Procedures}

Samples were obtained from fomites available on seven rooms of an Adult Intensive Care Unit of a private hospital in Rio de Janeiro with the capacity to treat any medical-surgical condition. Sampling was carried out between January and June 2009. The Adult Intensive Care Unit provides privacy and surveillance in seven individual rooms, each one with individual ventilation and air filtration systems.

All hospital cleaning protocols are performed twice a day routinely, emphasizing that after discharge of the patient's, the room undergoes a more rigorous process of disinfection. Weekly, the hospital performs track of colonization of mechanically ventilated patients, by surveying methicillin resistant Staphylococcus aureus (MRSA), Acinetobacter baumannii (MDR), and gram-negative bacillus (BGN) using tracheal and rectal swabs.

The sites were chosen to represent areas commonly in contact with hands. At least $50 \%$ of fomite areas (e.g., companion chairs) were scraped with swabs and dipped in Dulbecco's modified eagle's medium (DMEM-Gibco ${ }^{\mathbb{R}}$, Grand Island, NY), $\mathrm{pH} 7.2$, as described previously [Ganime et al., 2012]. HAdV were investigated in 141 samples, 73 previously positive for RVA, and 68 negative for RVA that were selected randomly [Ganime et al., 2012].

\section{Controls}

HAdV type 2 and DMEM were used as positive and negative controls, respectively, for all methodologies used [Leite et al., 1985]. To avoid cross-contamination, all molecular and cell cultures procedures were performed in different rooms, with UV decontamination.

\section{Nucleic Acids Extraction of Swab}

For nucleic acid extraction, guanidinium thiocyanate-silica method was adapted as described previously [Boom et al., 1990; Gallimore et al., 2004].

\section{Human Adenovirus Detection and Quantification}

Nucleic acids extracted from swabs were quantified using TaqMan ${ }^{\mathbb{B}}$ qPCR, targeting the conserved region segment of the first HAdV hexon gene part [Hernroth et al., 2002].

\section{Virus Viability Assay}

Samples presenting a high genomic quantification by TaqMan ${ }^{\circledR}$ qPCR cycle threshold $(\mathrm{Ct})<38$ were selected for investigation of viral viability using the integrated cell culture/nested-PCR (ICC/nPCR) assay. HAdV strains were propagated into 80-90\% confluent A549 and HEp2c cell lines supplemented with $2 \%$ FBS as described previously [Cromeans et al., 2008]. Nested-PCR was performed targeting a segment from the conserved region of the HAdV hexon gene to confirm HAdV isolation [Allard et al., 2001].

\section{Nucleotide Sequencing}

Purified DNA obtained from nested-PCR products were sequenced in both directions using Nehex3deg and Nehex4deg primers [Allard et al., 2001]. Generation of contiguous sequences and pairwise alignments of the HAdV hexon gene $171 \mathrm{bp}$ inter-primer region were performed at the Platform for DNA Sequencing (PDTIS; Oswaldo Cruz Foundation, Rio de Janeiro, Brazil).

\section{Statistical Analysis}

Statistical analysis was performed using the chisquare test as implemented by Epi info ${ }^{\circledR}$ software, version 3.5.1, and the two-tailed Fisher's exact test. The threshold for statistical significance was $P<0.05$.

\section{RESULTS}

Sixty-three out of 141 (44.7\%) fomites were positive for HAdV using TaqMan ${ }^{\circledR}$ qPCR. The viral load ranged from $2.48 \times 10^{1}$ to $2.1 \times 10^{3}$ genomic copies per millilitre $(\mathrm{gc} / \mathrm{ml})$. The Chlorhexidine ${ }^{\circledR}$ dispensers presented the highest viral load $\left(2.1 \times 10^{3} \mathrm{gc} / \mathrm{ml}\right)$, 
although the most frequently contaminated surface was the common trash bin covers followed by the TV remote control.

The analysis of fomites from rooms showed that HAdV was detected in all seven rooms of the Adult Intensive Care Unit, with a detection percentage ranging from 12.7 to $19 \%$. The room that presented the highest percentage of detection (19\%) was located farther from the room occupied by the medical staff.

Table I summarize the results obtained in the present study compared with RVA previous detection showing a mixed contamination in $31.2 \%(44 / 141)$ of analyzed samples. The statistical analysis demonstrated that the probability of a sample to be HAdV positive is 2.16 times $(P<0.05)$ higher when it is also RVA positive.

The rate of HAdV detection in the first months of the study (January [25/45, 55.6\%] and February [32/ $34,94.1 \%]$ ) was significantly higher than in the following months: March (1/16, 6.3\%), April (2/12, $16.7 \%)$, May $(1 / 20,5 \%)$, and June $(2 / 14,14.3 \%)$ $(P<0.05)$.

HAdV were isolated from 5 out of 10 investigated samples using A549 and/or HEp2c cell lines. Two samples, collected from telephone handles and common trash bin covers, demonstrated viability by ICC/ nPCR using A549 cell line. The samples collected from the common trash bin covers could be isolated in both cell lines (A549 and HEp2c). Samples collected from alcohol gel dispensers $(\mathrm{n}=2)$ and Chlorhexidine ${ }^{\circledR}$ dispensers $(n=1)$ were isolated in HEp2c cell line.

All isolates were confirmed as HAdV by nt sequencing presenting blast homology ranging from $96 \%$ to $98 \%$, one of which characterized as specie B, serotype 3 (HAdV-3).

\section{DISCUSSION}

The percentage and concentration of HAdV detected on fomites are consistent with previous data concerning their stability in environmental samples [Rutala et al., 2006; Carducci et al., 2011]. HAdV have been described as resistant to environmental stressors as disinfectants when deposited on fomites, recovered from dry inanimate surfaces from 7 days to 3 months [Kramer et al., 2006; Rutala et al., 2006].

In this study, environmental mixed contamination with HAdV and RVA was demonstrated corroborating data that shows mixed infection on hospital surfaces with gastroenteric viruses [Gallimore et al., 2006]. Virus survival on surfaces depends on several conditions although the most important contribution so far is the type of material/fluid in which it is discharged [Sattar, 2004]. Additionally, the type of surface can also influence the detection of these viruses. Abad et al. [1994] show that RVA persists longer than enteric HAdV when dried on porous and non-porous fomites. That information was not evaluated in this study, but may explain the presence of RVA in HAdV negative samples.
A significant decrease in the percentage of HAdV detection $(P<0.05)$ from March onwards was similar to the one previously observed for RVA [Ganime et al., 2012], although the detection of HAdV was significantly higher $(P<0.05)$ than the RVA in the first 2 months of the investigation (January and February). That reduction resulted from changing of both cleaning and disinfection procedures after finding RVA spread in hospital settings [Ganime et al., 2012]. The change of strategy in cleaning procedures resulted not only in the decrease of viral contamination, but also in the control of hospital infections by Acinetobacter spp. (data not shown). Those data emphasize the importance of preventive and corrective measures to reduce both direct and indirect transmission of microorganisms. Wilhelmi et al. [2003] support that hand hygiene before and after contact with patients or with objects that may be contaminated, as essential to disinfect contaminated surfaces. Training techniques of hand washing, for healthcare professionals, relatives, and visitors should be frequently provided especially those who attend any Intensive Care Unit [Soule et al., 1999]. This finding is supported by Ansari et al. [1988] who stated that the hands can donate or receive virus during occasional contact with animate and inanimate surfaces.

The negligence in cleaning procedures and the lack of compliance in hand hygiene was noted in this study. HAdV was detected in all rooms investigated; however, the fact that the most frequently contaminated room were the ones located away from the medical staff revealing non-compliance with effective cleaning protocols caught our attention. This kind of human behavior could explain why the common trash bin covers were the most frequently contaminated surfaces with HAdV. Such observation led us to confirm the incorrect use of the trash bin by relatives, visitors, and health professionals, when making the use of the hands to open the trash bin covers instead of the pedal. The qPCR results also revealed that Chlorhexidine ${ }^{\circledR}$ dispensers presented the highest viral load, corroborating data that suggest that health professionals are not compliant with proper hand washing using soap and water [Soule et al., 1999; Gallimore et al., 2005, 2008; Kramer et al., 2006; Ganime et al., 2012].

The isolation of HAdV and RVA from fomites indicate that those viruses remain infectious and should be useful to monitor environmental contamination. The higher percentage of HAdV detection together with the availability of cells for their isolation, suggests the use of HAdV as an indicator of viral contamination of fomites. Despite the isolation of enteric HAdV (specie F [40 and 41]) is considered a difficult procedure to be carried out when compared to other HAdV species [Rigotto et al., 2011], G293 and A549 cell lines have been described for isolating and propagating those viruses [Cromeans et al., 2008]. RVA is known as a fastidious virus and its isolation 


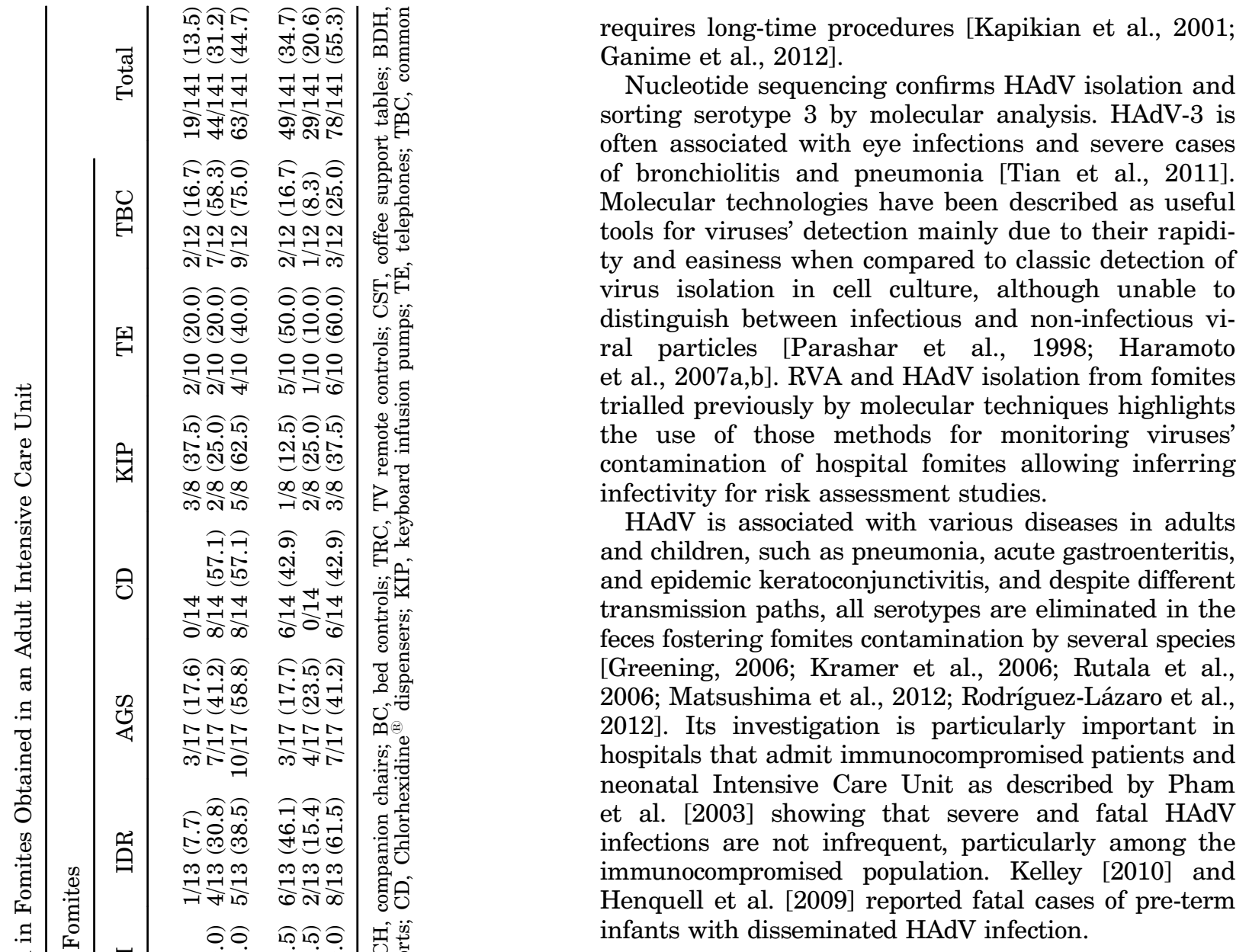

\section{CONCLUSION}

Considering the detection and isolation of HAdV and the totality of information, HAdV could be inferred as biomarkers for hospital fomites, as they can also be valuable to test the effectiveness of preventive measures and hygiene levels from hospital fomites, in order to alert healthcare professionals to the need of prevention measures and to ensure their compliance.

\section{REFERENCES}

Abad FX, Pinto RM, Bosch A. 1994. Survival of enteric viruses on environmental fomites. Appl Environ Microbiol 60:3704-3710.

Aitken C, Jeffries DJ. 2001. Nosocomial spread of viral disease. Clin Microbiol Rev 14:528-546.

Allard A, Albinsson B, Wadell G. 2001. Rapid typing of human adenoviruses by a general PCR combined with restriction endonuclease analysis. J Clin Microbiol 39:498-505.

Ansari SA, Sattar SA, Springthorpe VS, Wells GA, Tostowaryk W 1988. Rotavirus survival on human hands and transfer of infectious virus to animate and nonporous inanimate surfaces. J Clin Microbiol 26:1513-1518.

Bofill-Mas S, Pina S, Girones R. 2000. Documenting the epidemiologic patterns of polyomaviruses in human populations by studying their presence in urban sewage. Appl Environ Microbiol 66:238-245.

Boom R, Sol CJ, Salimans MM, Jansen CL, Wertheim-van Dillen PM, van der Noordaa J. 1990. Rapid and simple method for purification of nucleic acids. J Clin Microbiol 28:495-503. 
Carducci A, Verani M, Lombardi R, Casini B, Privitera G. 2011. Environmental survey to assess viral contamination of air and surfaces in hospital settings. J Hosp Infect 77:242-247.

Creamer E, Humphreys H. 2008. The contribution of beds to healthcare-associated infection: The importance of adequate decontamination. J Hosp Infect 69:8-23.

Cromeans TL, Lu X, Erdman DD, Humphrey CD, Hill VR. 2008. Development of plaque assays for adenoviruses 40 and $41 . \mathrm{J}$ Virol Methods 151:140-145.

Davanzo E, Frasson C, Morandin M, Trevisan A. 2008. Occupational blood and body fluid exposure of university health care workers. Am J Infect Control 36:753-756.

Filho EP, da Costa Faria NR, Fialho AM, de Assis RS, Almeida MM, Rocha M, Galvão M, dos Santos FB, Barreto ML, Leite JP. 2007. Adenoviruses associated with acute gastroenteritis in hospitalized and community children up to 5 years old in Rio de Janeiro and Salvador, Brazil. J Med Microbiol 56:313-319.

Gallimore CI, Cubbit D, du Plessis N, Gray JJ. 2004. Asymptomatic and symptomatic excretion of noroviruses during a hospital outbreak of gastroenteritis. J Clin Microbiol 42:2271-2274

Gallimore CI, Taylor C, Gennery AR, Cant AJ, Galloway A, Lewis D, Gray JJ. 2005. Use of a heminested reverse transcriptase PCR assay for detection of astrovirus in environmental swabs from an outbreak of gastroenteritis in a pediatric primary immunodeficiency unit. J Clin Microbiol 43:3890-3894.

Gallimore CI, Taylor C, Gennery AR, Cant AJ, Galloway A Iturriza-Gomara M, Gray JJ. 2006. Environmental monitoring for gastroenteric viruses in a pediatric primary immunodeficiency unit. J Clin Microbiol 44:395-399.

Gallimore CI, Taylor C, Gennery AR, Cant AJ, Galloway A, Xerry J, Adigwe J, Gray JJ. 2008. Contamination of the hospital environment with gastroenteric viruses: Comparison of two pediatric wards over a winter season. J Clin Microbiol 46:3112-3115.

Ganime AC, Carvalho-Costa FA, Mendonca MC, Vieira CB, Santos M, Costa Filho R, Miagostovich MP, Leite JP. 2012. Group A rotavirus detection on environmental surfaces in a hospital intensive care unit. Am J Infect Control 40:544-547.

Goodman ER, Platt R, Bass R, Onderdonk AB, Yokoe DS, Huang SS. 2008. Impact of an environmental cleaning intervention on the presence of methicillin-resistant Staphylococcus aureus and vancomycin-resistant enterococci on surfaces in intensive care unit rooms. Infect Control Hosp Epidemiol 29:593-599.

Greening GH. 2006. Human and animal viruses in food (including taxonomy of enteric virus). In: Goyal SM, editor. Virus in foods. 1st edition. St. Paul, USA: University of Minnesota. pp 28-29.

Haramoto E, Katayama H, Oguma K, Ohgaki S. 2007a. Quantitative analysis of human enteric adenoviruses in aquatic environments. J Appl Microbiol 103:2153-2159.

Haramoto E, Katayama H, Oguma K, Ohgaki S. 2007b. Recovery of naked viral genomes in water by virus concentration methods. J Virol Methods 142:169-173.

Henquell C, Boeuf B, Mirand A, Bacher C, Traore O, Déchelotte P, Labbé A, Bailly JL, Peigue-Lafeuille H. 2009. Fatal adenovirus infection in a neonate and transmission to health-care workers. $\mathrm{J}$ Clin Virol 45:345-348.

Hernroth BE, Conden-Hansson AC, Rehnstam-Holm AS, Girones R, Allard AK. 2002. Environmental factors influencing human viral pathogens and their potential indicator organisms in the blue mussel, Mytilus edulis: The first Scandinavian report. Appl Environ Microbiol 68:4523-4533.

Horwitz MS. 1996. Adenoviruses. In: Fields BN, Knipe DM, Howley PM, editors. Fields virology. 3rd edition. Philadelphia, PA: Lippincott-Raven Publishers. pp 2149-2171.

Kapikian AZ, Hoshino Y, Chanock RM. 2001. Rotaviruses. In: Fields BN, Knipe DM, Howley PM, editors. Fields virology. 4th edition. Philadelphia, PA: Lippincott Williams \& Wilkins Publishers. pp 1787-1833.

Katayama H, Haramoto E, Oguma K, Yamashita H, Tajima A, Nakajima H, Ohgaki S. 2008. One-year monthly quantitative survey of noroviruses, enteroviruses, and adenoviruses in wastewater collected from six plants in Japan. Water Res 42 $1441-1448$
Kelley CJ. 2010. A fatal case of neonatal adenovirus infection. Neonatal Netw 29:297-305.

Kramer A, Schwebke I, Kampf G. 2006. How long do nosocomial pathogens persist on inanimate surfaces? A systematic review. BMC Infect Dis 6:130.

Leite JP, Pereira HG, Azeredo RS, Schatzmayr HG. 1985. Adenoviruses in faeces of children with acute gastroenteritis in Rio de Janeiro, Brazil. J Med Virol 15:203-209.

Lopman BA, Reacher MH, Vipond IB, Hill D, Perry C, Halladay T, Brown DW, Edmunds WJ, Sarangi J. 2004. Epidemiology and cost of nosocomial gastroenteritis, Avon, England, 2002-2003. Emerg Infect Dis 10:1827-1834.

Matsushima Y, Shimizu H, Kano A, Nakajima E, Ishimaru Y, Dey SK, Watanabe Y, Adachi F, Suzuki K, Mitani K, Fujimoto T, Phan TG, Ushijima H. 2012. Novel human adenovirus strain. Bangladesh Emerg Infect Dis 18:846-848.

Myrmel M, Berg EMM, Grinde B, Rimstad E. 2006. Enteric viroses in inlet and outlet samples from sewage treatment plants. J Water Health 4:197-209.

Parashar UD, Bresee JS, Gentsch JR, Glass RI. 1998. Rotavirus. Emerg Infect Dis 4:561-570.

Pham TT, Burchette JL, Jr., Hale LP. 2003. Fatal disseminated adenovirus infections in immunocompromised patients. Am J Clin Pathol 120:575-583.

Pina S, Puig M, Lucena F, Jofre J, Girones R. 1998. Viral pollution in the environment and in shellfish: Human adenovirus detection by PCR as an index of human viruses. Appl Environ Microbiol 64:3376-3382.

Puig M, Jofre J, Lucena F. 1994. Detection of adenoviruses and enteroviruses in polluted waters by nested PCR amplification. Appl Env Microbiol 60:2963-2970.

Rigotto C, Sincero TC, Simões CM, Barardi CR. 2005. Detection of adenoviruses in shellfish by means of conventional-PCR, nestedPCR, and integrated cell culture PCR (ICC/PCR). Water Res 39:297-304.

Rigotto C, Hanley K, Rochelle PA, De Leon R, Barardi CRM, Yates MV. 2011. Survival of adenovirus types 2 and 41 in surface and ground waters measured by plaque assay. Environ Sci Technol 45:4145-4150.

Rodríguez-Lázaro D, Cook N, Ruggeri FM, Sellwood J, Nasser A, Nascimento MS, D'Agostino M, Santos R, Saiz JC, Rzeżutka A, Bosch A, Gironés R, Carducci A, Muscillo M, Kovač K, DiezValcarce M, Vantarakis A, von Bonsdorff $\mathrm{CH}$, de Roda Husman AM, Hernández M, van der Poel WH. 2012. Virus hazards from food, water and other contaminated environments. FEMS Microbiol Rev 36:786-814.

Rutala WA, Peacock JE, Gergen MF, Sobsey MD, Weber DJ. 2006. Efficacy of hospital germicides against adenovirus 8, a common cause of epidemic keratoconjunctivitis in health care facilities. Antimicrob Agents Chemother 50:1419-1424.

Rzezutka A, Cook N. 2004. Survival of human enteric viruses in the environment and food. FEMS Microbiol Rev 28:441-453.

Sattar SA. Microbicides and the environmental control of nosocomial viral infections. J Hosp Infect 2004. 56:S64-S69.

Soule H, Genoulaz O, Gratacap-Cavallier B, Mallaret MR, Morand P, Francois P, Luu Duc Bin D, Charvier A, Bost-Bru C, Seigneurin JM. 1999. Monitoring rotavirus environmental contamination in a pediatric unit using polymerase chain reaction. Infect Control Hosp Epidemiol 20:432-434.

Thurston-Enriquez JA, Haas CN, Jacangelo J, Gerba CP. 2003. Inactivation of feline calicivirus and adenovirus type 40 by UV radiation. Appl Environ Microbiol 69:577-582.

Tian X, Su X, Li H, Li X, Zhou Z, Liu W, Zhou R. 2011. Construction and characterization of human adenovirus serotype 3 packaged by serotype 7 hexon. Virus Res 160:214-220.

Tuladar E, Hazeleger WC, Koopmans M, Zwietering MH, Beumer RR, Duizer E. 2012. Residual viral and bacterial contamination of surfaces after cleaning and disinfection. Appl Environ Microbiol 78:7769-7775

Wilhelmi I, Roman E, Sanchez-Fauquier A. 2003. Viruses causing gastroenteritis. Clin Microbiol Infect 9:247-262. 